\title{
Child Poverty in a Regional Perspective: A Study of Sweden 1990 and 2010
}

\author{
DANIEL RAUHUT \\ University West, Dept. of Social and Behavioural Studies, Trollhättan, Sweden \\ SVANTE LINGÄRDE \\ Malmö University, Dept. of Health and Welfare Studies, Malmö, Sweden
}

\begin{abstract}
When the issue of welfare is addressed in Sweden analysis is usually focused on the national level, in a smaller number of cases on the local level, but rarely on the regional level. Studies on poverty are no exception. The aim of this paper is to analyse child poverty in Sweden, from a regional perspective, in 1990 and 2010. A multivariate cross-section OLS regression model is used to estimate regional factors causing child poverty. Regional macro data is used. The findings indicate that old industrial regions experience greater child poverty. The statistical analysis shows that when the share offoreign-born individuals increases in the regional population, so does the regional share of children living on social assistance. Higher incomes lower the regional share of children living on social assistance.
\end{abstract}

Keywords: child poverty, foreign born, income, single parents, unemployment

\section{Introduction}

The majority of previous studies on child poverty in Sweden describe and analyse developments at the national level (Rauhut et al. 2006; Salonen 2002, 2012; Socialdepartementet 2001, 2004). Notwithstanding this general national level bias, several studies have however focused on the development of child poverty at the municipal level. Comparisons are sometimes also made between municipalities. The organisation Save the Children ('Rädda Barnen') shows in several yearly reports that children growing up in wealthy suburban municipalities - such as Danderyd, Täby and Vellinge - are less exposed to poverty than children who grow up in suburban municipalities suffering from high unemployment (Botkyrka) or areas connected with social stigma - such as Rinkeby in Stockholm or Rosengård in Malmö (Angelin and Salonen 2012; Salonen 2002, 2012).

Studies focusing on regional differences however are rare. Indeed, very few studies have been produced on the regional dimension of poverty in Sweden and even in such cases they often only mention the issue of child poverty briefly (Dahlberg et al. 2008; Rautio 2002). 
A report from Save the Children shows that it is, in the main, three groups of children on the margins of general welfare state coverage in Sweden that are most exposed to poverty: children with an immigrant background, children in the suburbs of the metropolitan areas and children with a single parent. The differences between children are also marked (and the gaps are increasing) between the poorest and the richest groups of children, between municipalities and between areas within one and the same town. The main conclusion reached is that child poverty in Sweden has to a large extent become a metropolitan problem, thus impacting on the issue of housing segregation as well as those of economic and social exclusion (Salonen 2012).

As research has thus far seemed to neglect the regional perspective on child poverty this study attempts to address this basic omission. The aim of this paper is to describe and analyse the regional dimension of child poverty in Sweden during the period 1990-2010. Consequently, the limited nature of the research undertaken in line with this perspective makes the paper, at this stage, rather explorative in nature. This paper raises four questions that need to be answered: (1) What is the current 'state of the art' in terms of research on the regional dimension? (2) In which regions is child poverty high and low? (3) Why is child poverty higher in some regions and lower in others? (4) What are the causes of child poverty from a regional perspective?

As national studies conceal all geographical divergence and studies on municipalities usually lead to a fragmented picture on social as well as structural changes in society, we argue that the regional level, however, enables to identify geographical divergence as well as to identify how social and structural changes impact different parts of a country. The 'region' in this paper refers to the Swedish administrative unit 'län', an administrative unit between the local municipalities and the national level represented by the government. In Eurostat data län is equivalent to the NUTS 3 level.

Child poverty will be measured by an indirect indicator: the share of persons aged 0-17 living on social assistance in a regional population. Different indicators measure different aspects of poverty (Kangas and Ritakallio 1998), thus it is not possible, generally, to say that one indicator is a better measure than others. The term indirect measures usually relates to different kinds of income indicators; given a certain income it can be assumed that the individual or the household can uphold a certain material standard. The direct measures focus on what the individual in reality owns and consumes (Socialstyrelsen 1997). To define child poverty as the number of persons aged 0-17 living on social assistance in a regional population has one clear methodological advantage as no changes in definitions or classifications have been made during the studied period. The definitions in respect of several of the variables used here, namely, unemployment, income, transfers and sickness, have changed between 1990 and 2010. Although the use of harmonised data has corrected and adjusted the information in the indicators it is well known that it is difficult to conduct longer historical analysis 
methodologically. For some indicators information is simply missing: for married couples the divorce rate can be used as a proxy-variable for family dissolution, but this kind of information is missing for unmarried but cohabiting couples.

\section{Previous research on regional patterns of child poverty}

Rautio (2002) analyses regional expenditures on poverty during the period 1920-1955. He finds significant regional differences with the highest expenditures found in the northernmost regions. The results imply that the regional economic structure has a significant impact on regional expenditures on poverty: agrarian regions had significantly lower expenditures than industrial regions. During the period analysed in the study the northernmost regions did have a significant excess of births, and this additional labour could not subsequently be employed by either industry or the service sector. During the period of the study a national labour market did not exist, thus the surplus population generally had to make a living as smallholders (in the agricultural sector).

The population supported by poor relief during the period 1920-1955 was significantly younger in the northernmost regions than in the rest of the country. It must, however, be born in mind that 'poor relief' is not a comparable measure - either philosophically or materially - to the current notion of 'social assistance'. Rautio (2002) also finds evidence for a higher share of women working outside the domestic sector in regions with lower expenditures on poverty. He also finds a similar negative correlation between the share of children aged $0-15$ in the regional population and expenditures on poverty. According to Rautio (2002) this is due to the smaller cohorts born in the 1930s and to the introduction of a universal child allowance in 1948. The negative correlation between the share of children and expenditures on poverty remains however unexplained in his analysis.

Dahlberg et al. (2008) analyse the regional breakdown of the number of persons dependent on social assistance during the period 1990-2007. The highest shares were found in the regions of Västernorrland, Gävleborg, Västmanland, Örebro, Södermanland, Östergötland and Skåne in 2007, where between 4.51 and 6 percent of the population qualified for social assistance. The lowest share was found in the region of Halland (2.5 percent). The explanations given for these results focus on differences in the demographic structure, regional variation in the implementation of sickness benefits, regional differences in unemployment and in the share of refugees entitled to the so called introduction benefit (introduktionsersättning) from the government. Their conclusion is that a majority of the recipients of social assistance are relatively close to the labour market in the sense that their incomes from work constitute a majority of their disposable income. There is, however, a very well-defined group of recipients who are very distant from the regular labour market and their share of recipients has increased (Dahlberg et al. 2008). 
During the period 1990-2005 families with children, foreign-born families and those constituted by single parents dominated the grouping of recipients of social assistance in Sweden. The share of children 0-17 years old who grew up in households living on social assistance was highest in Västernorrland, Gävleborg, Dalarna, Västmanland, Örebro, Södermanland, Östergötland and Skåne in 2007. Between 7 and 9 percent of the children in these regions grew up in households qualifying for social assistance. The lowest shares of children (less than 5 percent) growing up under such conditions were found in Halland and Norrbotten. Dahlberg et al. (2008) therefore stress the strong correlation between the regional share of persons living on social assistance and the regional share of children living in households qualifying for social assistance.

The study by Renato Aguilar and Björn Gustafsson from 1993 should also be mentioned in this context. The empirical material here is from the mid-1980s while the focus is on the municipal determinants of social assistance. The divorce rate, it is revealed, had a major impact on the number of recipients, while the share of foreign-born in the population had no statistically significant effect. Nor did they find any significant effect in terms of unemployment on the need for social assistance, though there was a strong correlation where the persons involved did not qualify for unemployment insurance (Aguilar and Gustafsson 1993).

Several studies have focused on income-based child poverty, but these studies tend only to analyse developments at the national level (see e.g. Gustafsson et al 2003, Jonsson 2001 and Oxley et al. 2003). Gustafsson et al. (2013) however analyse child poverty at the town district level and their findings suggest that districts with a high share of adults who are dependent on social assistance also have a higher likelihood of child poverty.

\section{Children and the recipients of social assistance}

An indirect measure of absolute poverty is to use a politico-administrative budget line. The budget line for social assistance constitutes such a prospective measure (Rauhut 2011). The social assistance measure can be assumed to provide the recipient with a minimum-level of socially accepted standard of living (Rauhut 2002). It could, however, be argued that this indicator is just as arbitrary as an income-based indirect measure of poverty as the number of poor will change when the level of the politico-administrative budget line changes. The easiest way to decrease the number of poor in a country is to lower the threshold of the politico-administrative budget line, i.e. the poverty line; when the poverty line is lowered fewer persons are entitled to benefits. A high threshold in the politico-administrative budget line makes more persons entitled to social assistance. This paradox is called 'Ringen's Paradox' and is named after its founder (Ringen 1987).

Before the economic crisis of the early 1990s the highest shares of recipients in respect of social assistance were to be found in the Stockholm region and the regions of Södermanland, Västmanland and Gotland. This pattern has however changed signifi- 
cantly in the subsequent twenty years. Now the highest shares of recipients are to be found in the industrial regions of Södermanland, Östergötland, Örebro, Västmanland, Dalarna and Gävleborg.

About 11 percent of the children aged 0-17 in the regional population lived in households receiving social assistance in 1990. The regions with the highest shares were Stockholm, Södermanland, Östergötland, Örebro and Västmanland; in the regions of Uppsala, Gotland, Gävleborg and Skåne approximately 10 percent of the children aged 0-17 years lived in households that received social assistance in 1990. In 2010 10-12 percent of the children aged 0-17 lived in households receiving social assistance in the regions of Södermanland, Östergötland, Örebro, Västmanland and Gävleborg. These regions were prosperous with a very high economic growth during Sweden's 'golden industrial era' of the 1950s and 1960s.
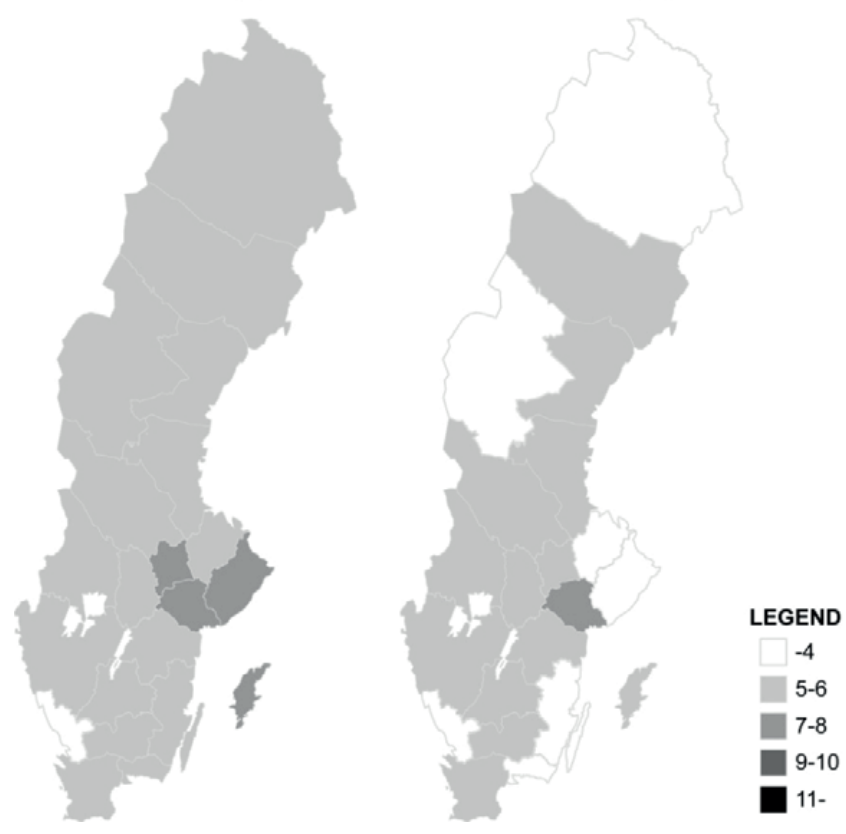

Map 1. The regional share of recipients of social assistance in percent of the regional population 1990 and 2010.

Source: The database of the National Board of Health and Welfare (Socialstyrelsen) 

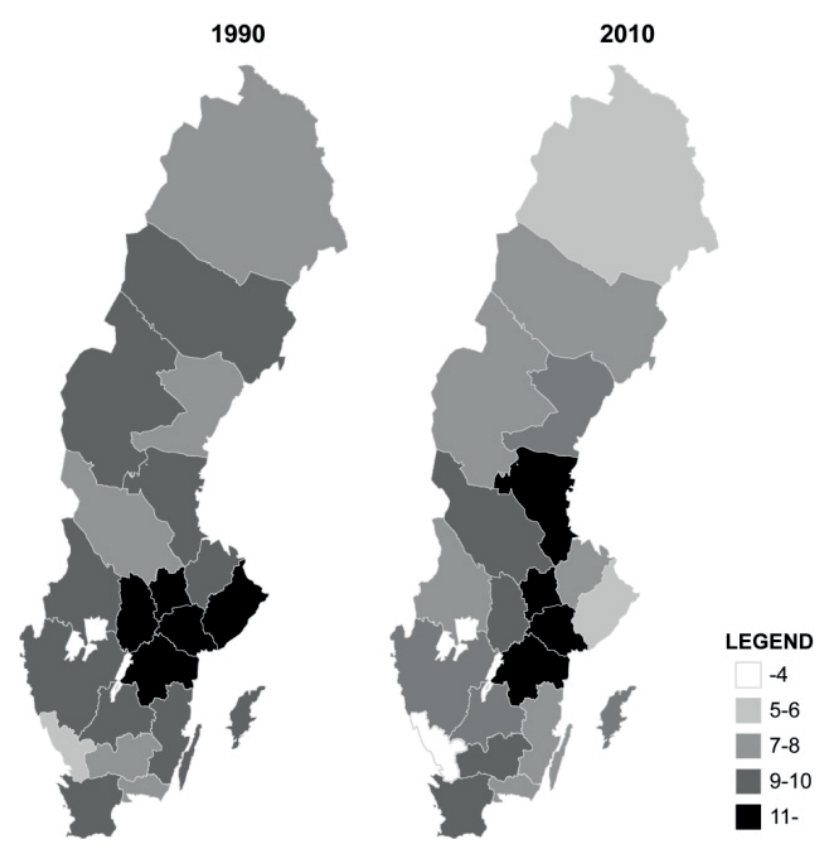

Map 2. The regional share of recipients of social assistance aged $0-17$ of the regional population 1990 and 2010.

Source: The database of the National Board of Health and Welfare (Socialstyrelsen)

A 1990

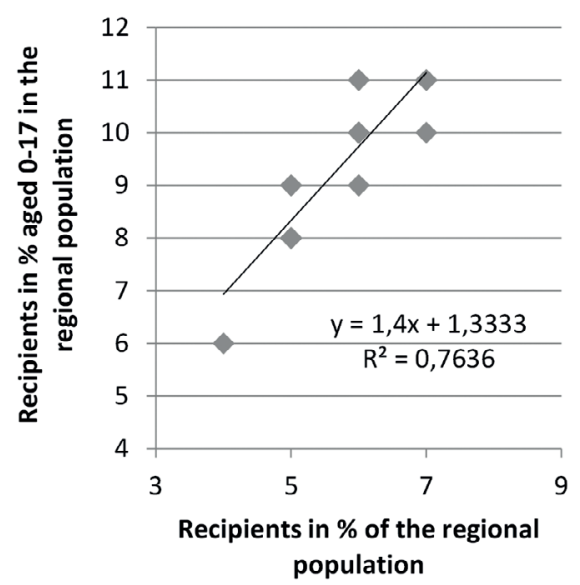

B 2010

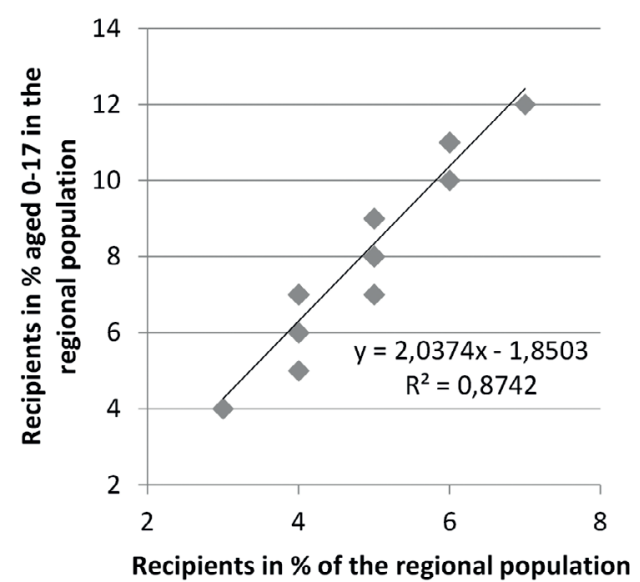

Figure 1. The share of recipients in the regional population and the share of recipients of social assistance aged 0-17 in the regional population 1990 and 2010 $(\mathrm{N}=21)$.

Source: Own estimations from the database of the National Board of Social Welfare 
A very strong correlation exists between the share of recipients in the regional population and the share of recipients aged 0-17 in the regional population for both 1990 and 2010 (figure 1). Furthermore, there is a strong correlation between those regions which showed a high share of recipients of social assistance aged 0-17 in 1990 and in 2010 (figure 2). The regions with a high share of social assistance recipients aged 0-17 in 1990 also experienced this in 2010.

The economic crisis of the 1990s marks the culmination point of the deindustrialisation process the Swedish economy has been undergoing since the end of the 1960s. Today regions such as Södermanland, Östergötland, Örebro, Västmanland, Dalarna and Gävleborg have retained an obsolete branch economy industrial structure and continue to suffer from an interrupted or unfinished process of structural change (Eðvarðsson et al. 2007). In these regions the industrial sector declined significantly during the economic crisis of the 1990s. While the service sector recovered quickly, the industrial and manufacturing sector did not (Rauhut and Kahila 2008).

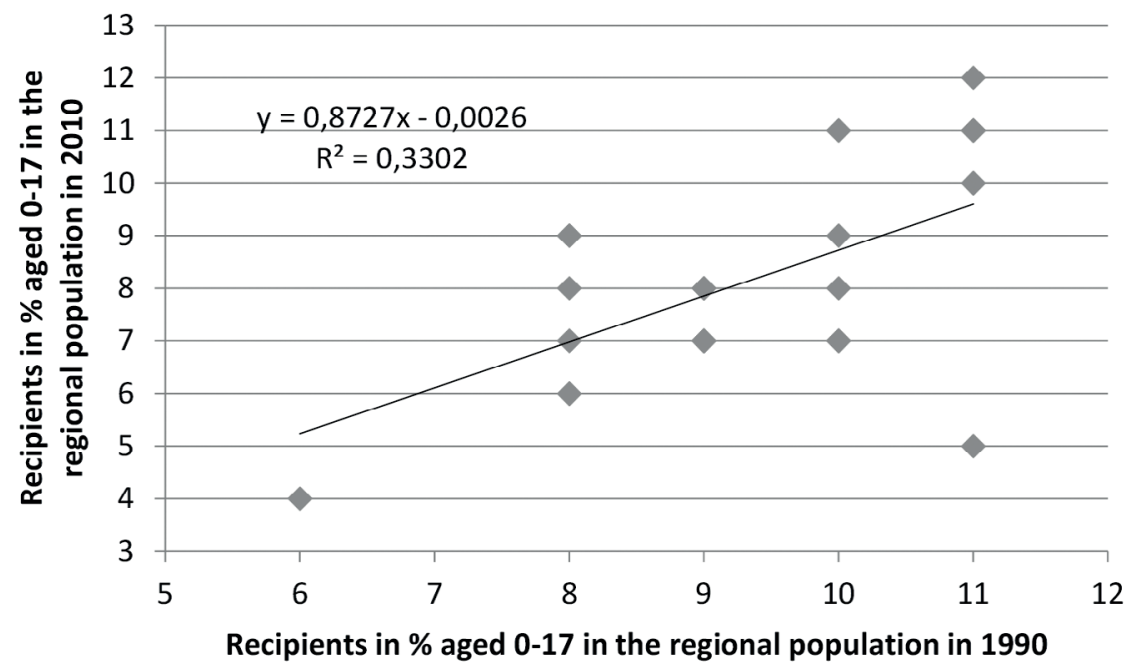

Figure 2. The correlation between the regional share of recipients of social assistance in 1990 and in $2010(\mathrm{~N}=21)$.

Source: Own estimations from the database of the National Board of Social Welfare

Today these regions suffer from high unemployment rates (young adults, immigrants, persons aged 50+), high sickness leave rates, a high share of early retirees and a high share of social transfers to the population (Rauhut and Kahila 2012). Factors like these usually generate a significant need for support by society (Rauhut 2013; Salonen 1994), and therefore it is not very surprising to find such high shares of children aged 0-17 in households receiving social assistance in these regions. 


\section{Relative poverty}

An indirect measure of relative poverty is the share of population with less than 50 percent of the median of disposable income. Children who grow up in households with a disposable income of less than 50 percent of the median disposable income can be considered poor in relative terms. The variable income level has changed on several occasions over time when it comes to definition and classification. The same is true for the consumption unit scale. This creates a methodological problem in the analysis. It must also be noted that changes in the average income in a municipality or region will change the number of poor. Kangas and Ritakallio (1998) argue that if the half median income measure is used as an indicator of poverty, it is important to understand that the share of poor in the population will be related to the general income distribution rather than to the changes in income in relation to those who are termed poor. When the income distribution changes so will the number of poor.

Income standard is frequently used in surveys of the economic standard of a household and this indicator has thus been used extensively by Statistics Sweden. This indicator is created by dividing the disposable income of a household by an indicator expressing its expenditures. It is based upon the assumption that all members in a household have similar consumption patterns (Gustafsson et al. 2003). This kind of assumption is practical, but problematic to deal with.

Income-related indicators reveal no information on 'stop gap' activities, i.e. whether the household is engaged in selling assets to maintain consumption. Moreover, we do not know whether the parents reduce or defer their own consumption in favour of their children, nor do we know whether the household is self-sustaining in any sense. Such factors as wealth, participation in the informal economy, and whether the person lives on the countryside or in a city (income is higher in cities, but so are the costs of living) etc. are not considered although they have an impact on income as well as the standard of living (Rauhut 2011). Lastly, we are given no information on why the income differences exist, which is of the utmost importance when analysing income poverty. Aspects such as human capital, discrimination, the negotiation power of trade unions, class, family, wealth, talent, cohort effects, luck and health have an impact on differences in incomes (see Rauhut 2011 for an overview). The common assumption regarding income and poverty is that a person will have an assumed standard of living corresponding with the income. It is also assumed that all persons have the same consumption patterns and needs.

In this study the indicator "low income" will be used and contrasted with "high income". Low income is defined as the income level of a person who lives in a household with a disposable income per consumption unit less than 60 percent of the median for all households. Although subject to problems similar to those of other income-based indicators of poverty, this indicator has the advantage of being comparable to how 
"poverty risk" is often conceived within the European Union. High income is defined as the income level of a person who lives in a household with a disposable income per consumption unit more than twice as high as the median for all households.

The scale of consumption units is related to the household structure. All expenditures will not increase proportionally with the number of persons in the household and this is controlled for in the consumption unit scale. If the expenditure is divided by a consumption unit for the household, it is assumed possible to compare expenditures in different kinds of households. The consumption unit weights are the following: single adult and the first adult in a married/cohabiting couple is 1.00 , spouse/cohabiting partner is 0.51 , additional adult in the household is 0.60 , first child aged $0-19$ is 0.51 , second and more children aged 0-19 are given the weight of 0.42 (SCB 2012). Thus the consumption unit scale is based on what individuals are assumed to consume, not what they consume in reality.

Income statistics are not presented by region or by municipality in the Statistics Sweden database, but instead by five categories of municipalities: metropolitan municipalities (storstäder), suburban municipalities (förortskommuner), major cities (större städer), commuter municipalities (pendlingskommuner) and other municipalities (övriga kommuner). Metropolitan municipalities (storstäder) refers to cities with more than 200,000 inhabitants (Stockholm, Göteborg, Malmö and Uppsala). Suburban municipalities (förortskommuner) refers to municipalities where at least 50 percent of the night resident population commute to a work in another municipality and where commuting is directed towards one of the metropolitan municipalities. Municipalities with a population between 50,000 and 200,000 inhabitants are classified as major cities (större städer). Commuter municipalities (pendlingskommuner) refers to municipalities (other than suburban municipalities) where at least 40 percent of the population commute to a work in another municipality. Municipalities not belonging to these first four categories are classified as other municipalities (övriga kommuner). A municipality can only belong to one of these five categories.

How has the disposable income per consumption unit developed between 1991 and 2010 ? In table 1 the disposable income per consumption unit for persons over 20 years of age increases by 32 to 38 percent in all municipal categories. Although this may give the impression of a general increase in wealth, such a conclusion should not be made. In tables 2 and 3 it is obvious that such a general increase is a statistical illusion. 
Table 1. Disposable income per consumption unit for persons over 20 years old. Median value, 1,000s SEK by municipal category, 1991 and 2010.

\begin{tabular}{lrrc}
\hline & 1991 & 2010 & change \\
\hline metropolitan & 153.4 & 211.7 & $+38 \%$ \\
suburban municipalities & 173 & 229.4 & $+33 \%$ \\
major cities & 151 & 200 & $+32 \%$ \\
commuter municipalities & 147 & 203.6 & $+38 \%$ \\
other municipalities & 143.9 & 197.9 & $+38 \%$ \\
\hline
\end{tabular}

Source: Statistics Sweden database

The share of persons in households with an income lower than 60 percent of the disposable income median has increased in all municipal categories between 1991 and 2010. In the metropolitan and the suburban municipalities this group has increased by 141 percent and 129 per cent respectively between 1991 and 2010. For the other municipal categories the increase is smaller, but still significant. This group of low income earners contains young adults, persons with a foreign background and single parents. When incomes are decreasing the children in these households will face a relatively higher risk of growing up in poverty (Socialstyrelsen 2007, 2010).

Table 2. The share of persons over 20 years old in households with an income lower than 60 per cent of the median disposable income, 1991 and 2010.

\begin{tabular}{lrrr}
\hline & $\mathbf{1 9 9 1}$ & $\mathbf{2 0 1 0}$ & Change \\
\hline metropolitan & 6.3 & 15.2 & $+141 \%$ \\
suburban municipalities & 4.1 & 9.4 & $+129 \%$ \\
major cities & 7.5 & 12.9 & $+72 \%$ \\
commuter municipalities & 8.2 & 11.1 & $+35 \%$ \\
other municipalities & 8 & 12.6 & $+58 \%$ \\
\hline
\end{tabular}

Source: Statistics Sweden database

While the share of persons with low incomes has increased so has the share of those with high incomes. Although the share of high income earners has increased in the metropolitan municipalities and the suburban municipalities, the increase is even larger, 338 percent, in the commuter municipalities. The increase of high income earners is also significant in major cities and other municipalities (100 percent and 123 percent respectively). 
Table 3. The share of persons over 20 years old in households with an income higher than 200 per cent of the median disposable income, 1991 and 2010.

\begin{tabular}{lrrr}
\hline & 1991 & 2010 & Change \\
\hline metropolitan & 6.4 & 10.3 & $+61 \%$ \\
suburban municipalities & 9.5 & 10.8 & $+14 \%$ \\
major cities & 3.3 & 6.6 & $+100 \%$ \\
commuter municipalities & 1.3 & 5.7 & $+338 \%$ \\
other municipalities & 2.2 & 4.9 & $+123 \%$ \\
\hline
\end{tabular}

Source: Statistics Sweden database

It was noted previously that an increase in the general level of income inequality will manifest itself as an increase in the number of poor (see Kangas and Ritakallio 1998). In tables 2 and 3 this is clearly the case. The changes in the general income distribution cannot be derived solely from an increase in the share of persons with a low income, but should also be seen in relation to an increase in the share of persons with a high income. When using income as an indicator of poverty no information is given in respect of why the income changes have occurred.

The disposable income of a household depends on the total work incomes as well as social transfers. During the last decades these have changed significantly. The share of social transfers in total household incomes has increased since 1975 while the share of incomes from work has decreased (Jansson et al. 2003). For families with children the share of social transfer income has increased even more (Gustafsson et al. 2003).

It is possible to assume that the decline in the share of disposable income originating in work is related to changes in employment patterns after the Swedish economic crisis of the early 1990s. Three marked changes in the employment structure have been observed: (1) The metropolitan areas and the Jönköping region have experienced an increase in employment; a minor increase in employment is observed in coastal towns and university towns, while rural and peripheral areas have experienced significant decreases in employment since the crisis in the early 1990s (Persson (Ed.), 2004). (2) The matching problems in the labour market have increased since the beginning of the 1990s. The jobs that disappeared in the traditional industrial regions were found in traditional 'Fordist' production in manufacturing and industry, while the new jobs have emerged in the knowledge-based and 'post-Fordist' service sector. One consequence of this has been a regional polarisation where employment and incomes have declined in the traditional industrial regions while the opposite development is found in the expansive metropolitan regions (Johansson and Persson 2001). (3) Many of the new jobs that have been created in the expansive service sector are now poorly paid low status jobs. The share of fixed contracts, where the period of employment only lasts for a limited time, is higher in this sector than in the labour market as a whole. This 
creates economic insecurity for those working under these conditions. The share of fixed contracts has, moreover, increased over time. Young adults and persons with an immigrant background usually have few other employment opportunities besides jobs with fixed contracts ( $\AA$ slund et al. 2006; Ekberg 2006; Pettersson 2006). Furthermore, it must be borne in mind that a higher share of persons are studying in 2010 than in 1990 - especially young adults and persons with an immigrant background - which also makes them more dependent on transfers while studying.

\section{A statistical analysis}

The structural change in the economy which Sweden has experienced in the form of de-industrialisation has led to a situation where young adults and persons with an immigrant background have great difficulty in establishing themselves on the labour market. Both groups show a high level of relative unemployment.

The discussion above also noted that income differences in society have increased with the result that many people find that they cannot consume goods and services in the same way in which they perceive that the surrounding population does. Children suffer from their parents' unemployment, sickness and low incomes; children of relatively young parents and of persons with immigrant backgrounds are also significantly impacted and experience a higher risk of poverty simply because their parents have not managed to establish themselves on the labour market. Children of single parents are particularly exposed to the risk of poverty.

A multiple regression model will be constructed to statistically estimate which factors have the greatest impact on child poverty. Child poverty will be measured as the share of those persons aged $0-17$ in the regional population who grow up in a household which is dependent on social assistance. This will be the dependent variable $\left(B_{\mathrm{i}, \mathrm{f}}\right)$ to be explained in the model. The following six independent variables will be used; the average income of work per person and region with a one year lag $\left(F_{\mathrm{i}, t-1}\right)$, the average social transfers per person and region with a one year lag $\left(T_{\mathrm{i}, t-1}\right)$, the share of those who are foreign-born in the regional population $\left(I_{\mathrm{i}, t}\right)$, the relative unemployment rate per region $\left.U_{\mathrm{i}, t}\right)$, the share of children who live with a single parent $\left(E_{\mathrm{i}, t}\right)$, and, finally, the regional sickness rate $\left(S_{\mathrm{i}, t}\right)$. The data for incomes and social transfers refers to data for $2009(t-1)$ and all other variables to data for 2010. Regions are denoted as $i$ in the model. In order to express elasticities the natural logarithm has been calculated for all variables. The model can be formalised in the following manner:

$$
B_{i, t}=\alpha+\beta_{1} I_{i, t}+\beta_{2} U_{i, t}+\beta_{3} E_{i, t}+\beta_{4} S_{i, t}+\beta_{5} F_{i, t-1}+\beta_{6} T_{i, t-1}+\varepsilon
$$

The result of this modelling process is illustrated in table 4 and termed model 1. This model is not however very good in explanatory terms, which is why the simplified 
models $2-5$ have been estimated. In all of the models two variables basically explain the share of the persons aged $0-17$ in the regional population who grow up in a household which is dependent upon social assistance: the share of foreign-born in the regional population and the average income of work per person and region with a one year lag. In model 5 the regional unemployment rate shows an almost statistically significant result.

Table 4. Multiple regression analysis. The dependent variable is the share of the persons aged 0-17 in the regional population who grow up in a household which is depending on social assistance in 2010. $t$-values within brackets.

\begin{tabular}{|c|c|c|c|c|c|}
\hline & Model 1 & Model 2 & Model 3 & Model 4 & Model 5 \\
\hline C & $\begin{array}{l}9.623 \\
(1.501)\end{array}$ & $\begin{array}{l}9.489^{\star} \\
(2.118)\end{array}$ & $\begin{array}{l}9.654^{*} \\
(2.368)\end{array}$ & $\begin{array}{l}12.268^{* *} \\
(3.162)\end{array}$ & $\begin{array}{l}10.732^{*} \\
(2.626)\end{array}$ \\
\hline Share of foreign born & $\begin{array}{l}.684^{*} \\
(2.201)\end{array}$ & $\begin{array}{l}.688^{*} \\
(2.510)\end{array}$ & $\begin{array}{l}.693^{*} \\
(2.647)\end{array}$ & $\begin{array}{l}.808^{* *} \\
(3.081)\end{array}$ & $\begin{array}{l}.652^{*} \\
(2.451)\end{array}$ \\
\hline Unemployment & $\begin{array}{l}.305 \\
(1.002)\end{array}$ & $\begin{array}{c}.298 \\
(1.453)\end{array}$ & $\begin{array}{c}.290 \\
(1.573)\end{array}$ & & $\begin{array}{l}.353^{\mathrm{a}} \\
(1.937)\end{array}$ \\
\hline Share of single parents & $\begin{array}{l}.246 \\
(1.157)\end{array}$ & $\begin{array}{c}.244 \\
(1.246)\end{array}$ & $\begin{array}{c}.236 \\
(1.337)\end{array}$ & $\begin{array}{c}.308 \\
(1.726)\end{array}$ & \\
\hline Sickness rate & $\begin{array}{l}-.012 \\
(-.030)\end{array}$ & & & & \\
\hline $\begin{array}{l}\text { Average income from } \\
\text { work, SEK 1000's }\end{array}$ & $\begin{array}{c}-.763^{\star} \\
(-2.142)\end{array}$ & $\begin{array}{l}-.759^{*} \\
(-2.431)\end{array}$ & $\begin{array}{l}-.743^{*} \\
(-2.792)\end{array}$ & $\begin{array}{l}-.878^{* *} \\
(-3.343)\end{array}$ & $\begin{array}{c}-.739^{*} \\
(-2.715)\end{array}$ \\
\hline $\begin{array}{l}\text { Average social transfers } \\
\text { per person, SEK } 1000 \text { 's }\end{array}$ & $\begin{array}{c}.032 \\
(.105) \\
\end{array}$ & $\begin{array}{c}.032 \\
(.107) \\
\end{array}$ & & & \\
\hline Adj.R2 & .354 & .397 & .434 & .385 & .408 \\
\hline d.f. & 14 & 15 & 16 & 17 & 17 \\
\hline D-W & 1.541 & 1.538 & 1.531 & 1.281 & 1.718 \\
\hline
\end{tabular}

Models 1-4 all have problems with autocorrelation, which means that the residuals are correlated with each other with the result that the precision of the prediction will be low (Andersson et al. 1994, Djurfeldt et al. 2010). The Durbin-Watson value (DW) should be as close to 2 as possible, which is not the case in models 1-4. In model 5 the $\mathrm{D}-\mathrm{W}$ value is close enough to 2 to not make the result misleading. Model 5 can also explain almost 41 percent of the linear causality between, on the one hand, the share of those persons aged $0-17$ in the regional population who grow up in a household which is dependent upon social assistance, and, on the other hand, the share of foreign-born persons in the regional population, the regional average income of work per person and the relative level of regional unemployment. 
What information does model 5 contain? When the share of foreign-born people increases in the regional population by one unit the share of those persons aged $0-17$ in the regional population who grow up in a household which is dependent upon social assistance will increase by 0.652 units; when the average income of work per person and region, with a one year lag, increases by one unit the share of those persons aged 0-17 in the regional population who grow up in a household which is dependent upon social assistance will decrease by 0.739 units. Both of these coefficients are statistically significant at the $5 \%$ level, i.e. with at least $95 \%$ probability that they would be lower in the absence of a systematic connection between the variables.

The result for relative regional unemployment does not have a coefficient which is statistically significant at the $5 \%$ level (but at the $7 \%$ level); this result thus has a higher probability of simply being the outcome of chance. Nevertheless, when the regional unemployment rate increases by one unit the share of the persons aged 0-17 in the regional population who grow up in a household which is dependent upon social assistance will increase by 0.353 units.

When comparing the results obtained in this study with those published by Save the Children in Sweden (Rädda barnen) many similarities can be found. It must be stressed, however, that Save the Children in Sweden analyse child poverty at either the national level or the municipal level while in the context of this study child poverty is analysed at the regional level. Nevertheless, child poverty appears, in both studies, to be primarily a problem associated with integrating foreign-born people into Swedish society in general and the Swedish labour market in particular. A further similarity in terms of results across both studies is that child poverty is generally found in geographical areas with a low average income.

Differences do however also emerge between the two studies. Save the Children in Sweden (Rädda barnen) argue that children in single parent households are more exposed to child poverty than children in households with both parents present. This result is not confirmed here. One reason why the results in this study does not confirm that conclusion may be that this study focus on the regional level while Save the Children in Sweden (Rädda barnen) focus, on the one hand, on municipalities and the town district level and, on the other hand, on the aggregated national level. A second possible explanation may be that it is not living in a single parent household per se which increases the risk for child poverty, but that the household only has one income. If this is the case, then this aspect is dealt with in the income variable used in the model (which turned out to be statistically significant). A third possible explanation may be that an analysis at a regional level does not identify the housing segregation mechanisms. In studies on income poverty based on micro-data at the town district level these marginalisation mechanisms are likely to be statistically significant. 


\section{Concluding remarks}

The aim of this paper is to describe and analyse the regional dimension of child poverty in Sweden during the period 1990-2010. This kind of analysis has not previously been undertaken which of itself renders this paper rather explorative in nature. The first question raised addressed the 'state of the art' in terms of previous research. Regional analyses of Swedish data are few in number. Two studies were found, of which one analyses the period 1920-1955. The organisation Save the Children in Sweden (Rädda barnen) has, in a number of non-scientific reports, studied the structure and development of child poverty in Sweden at an aggregated national level and at a municipal level.

The second question was in which regions child poverty was high and low. Child poverty, defined as the share of the persons aged 0-17 in the regional population who grow up in a household dependent upon social assistance, has in general declined over the period 1990-2010. At the same time, the analysis shows that child poverty remains at a consistently high level in regions such as Östergötland, Södermanland and Västmanland, and that child poverty has actually increased in traditional industrial regions such as Dalarna, Gävleborg and Västernorrland during this period.

The third question concerned why child poverty is higher in some regions and lower in others. The regions with the highest levels of child poverty have retained an obsolete branch economy industrial structure and continue to suffer from an interrupted or unfinished structural change process. These regions experience many problems simultaneously and have done so since the onset of the economic crisis of the early 1990s. The problems these regions experience include high relative unemployment rates for marginal groups in the labour market (young adults, immigrants and persons aged $50+$ ), high sickness leave rates, high early retirement rates and high social transfers to households. If there are children in the household they will be exposed to poverty to a larger extent than children in regions with a modern economic structure that do not suffer from the multifaceted matrix of social problems on display here.

The fourth question was what causes child poverty in a regional context? The results of the statistical analysis indicate that when the share of foreign-born people in the regional population increases, so will child poverty and when the average income of work increases child poverty will decrease. These results are confirmed by the findings in the reports of Save the Children in Sweden (Rädda barnen) at the national and municipal levels. The statistical analysis also suggests that an increase in regional relative unemployment may increase child poverty at the regional level, though it should be noted that the result obtained here is just below the threshold for statistical significance.

One possible explanation for this is given by Aguilar and Gustafsson (1993) and Socialstyrelsen (2010). A period of unemployment without financial support in the form of unemployment insurance leads to an acute need for support by means of social assistance programmes rather than unemployment where coverage from the 
unemployment insurance system is received. In other words, it is not unemployment per se that leads to an increase in the regional level of child poverty, but rather parents' not being included in the unemployment insurance.

This paper has shown that the structure and variation in the regional child poverty is complex as well as multifaceted. Some of the findings here suggest support for those of previous studies, e.g. that the risk of child poverty is higher for children with foreignborn parents and that children in households with low incomes are more exposed to poverty than children from median income and high income households. The paper has also identified that the highest shares of persons aged 0-17 in the regional population who grow up in households dependent upon social assistance are found in traditional industrial regions and that child poverty has increased in these regions between 1990 and 2010. This suggests that not only do individual problems influence the development of child poverty but also that structural problems in the welfare system appear also to be significant in this respect.

\section{Acknowledgements}

The authors are indebted to Björn Gustafsson and Chris Smith for comments on an earlier version of this paper and to Elisabetta Troglio for producing the maps. 


\section{References}

\section{Statistics}

Arbetsförmedlingen (National Employment Service), www.arbetsformedlingen.se

Försäkringskassan (The Swedish Social Insurance Agency), www.forsakringskassan.se

Socialstyrelsens statistikdatabas (The National Board of Health and Welfare statistical database), www.socialstyrelsen.se

Statistiska centralbyråns statistikdatabas (Statistics Sweden statistical database), www.scb.se

\section{Literature}

Aguilar, R. \& Gustafsson, B. (1993). Kommunerna och socialbidraget [The Municipalities and Social Assistance]. Statsvetenskaplig Tidskrift 96(2), 185-91.

Angelin, A. \& Salonen, T. (2012) Lokala handlingsstrategier mot barnfattigdom [Local Action Stategies against Child Poverty]. Kommissionen för ett socialt hållbart Malmö.

Andersson, G., Jorner, U. \& Ågren, A. (1994). Regressions- och tidsserieanalys [Regression and Time Series Analysis]. Lund: Studentlitteratur.

Åslund, O., Erikson, R., Nordström Skans, O. \& Sjögren, A. (2006) Fritt inträde? Ungdomars och invandrares väg till det första arbetet [Free Entry? Youths' and Immigrants' Way to the First Job]. Stockholm: SNS förlag.

Dahlberg, M., Edmark, K., Hansen, J. \& Mörk, E. (2008). Fattigdom i folkhemmet [Poverty in the Swedish 'Folkhem']. Stockholm: SNS förlag.

Djurfeldt, G., Larsson, R. \& Stjärnhagen, O. (2010). Statistisk verktygslåda [Statistical Toolbox]. Lund: Studentlitteratur.

Eðvarðsson, I.R., Heikkilä, E., Johansson, M., Johannesson, H., Rauhut, D., Schmidt, T.D., Stambøl, L.S. \& Wilkman, S. (2007). Demographic Change, Labour Migration and EU-Enlargement - Relevance for the Nordic Regions. Stockholm: Nordregio.

Ekberg, J. (2006). Försvårar arbetsrätten för invandrarna på arbetsmarknaden [Do Labour Market Regulations Create Difficulties for Immigrants in the Labour Market]? In: Rauhut, D. \& Falkenhall, B. (Eds.) Arbetsrätt, rörlighet och tillväxt [Labour Market Regulations, Mobility, and Growth]. Stockholm: Institutet för tillväxtpolitiska studier.

Gustafsson, B., Johansson, M. \& Palmer, E. (2003). Barnens inkomststandard under 90-talets djupa recession och den följande återhämtningen [The Income Standard of Children during the Deep Recession of the 90s and the Ensuing Recovery]. Socialvetenskaplig tidskrift 2003(1), 3-23.

Gustafsson, B., Katz, K. \& Österberg, T. (2013). Boendesegregation, bakgrund och barnfattigdom [Segregation of Living, Background, and Child Poverty]. In: Rauhut, D. (Ed.) Barnfattigdom [Child Poverty]. Lund: Studentlitteratur.

Jansson, K., Karlsson, Å. \& Lundberg, P. (2003) "Inkomstfördelningen 1975-2001" [The Distribution of Income 1975-2001]. In: Välfärd och ofärd på 1990-talet [Good Times and Hard Times in Sweden During the 1990s]. Levnadsförhållanden rapport 100 [Living Conditions Report 100]. Stockholm: SCB

Johansson, M. \& Persson, L.O. (2001). Local labour market performance in the knowledge economy. In: Persson, L.O. (Ed.) Local labour market performance in Nordic countries. Stockholm: Nordregio. 
Jonsson, J.O. (2001). Ekonomiska och materiella resurser [Economic and Material Resources]. In: Jonsson et al. (Eds.) Barn och ungdomars välfärd [Welfare of Children and Youths]. Kommittén Välfärdsbokslut SOU 2001:55. Stockholm: Fritzes förlag.

Kangas, O. \& Ritakallio, V.M. (1998). Different Methods - Different Results? Approaches to Multidimensional Poverty. In: Andre $\beta$, A. (Ed.) Empirical Poverty Research in a Comparative Perspective. Aldershot: Ashgate.

Oxley, H., Dang, T.T., Förster, M.F. \& Pellizzari, M. (2003). Income inequalities and poverty among children and households with children in selected OECD countries. In: Vleminckx, K. \& Smeeding, T.M. (Eds.) Child well-being, child poverty and child policy in modern nations. What do we know? Bristol: Policy Press.

Persson, L.O. (Ed., 2004). Economic Renewal and Demographic Change. Stockholm: Nordregio.

Pettersson, L. (2006). Arbetets betydelse för välfärden [The Importance of Labour for Welfare]. In: Södersten, B. (Ed.) Den problematiska tryggheten - välfärdsstaten under tre decennier [The Problematic Security - The Welfare State during Three Decades]. Stockholm: SNS förlag.

Rauhut, D. (2002). Fattigvård, socialbidrag och synen på fattigdom i Sverige 1918-1997 [Poor Relief, Social Assistance, and the Attitude to Poverty in Sweden 1918-1997]. Stockholm: Almqvist \& Wiksell International.

Rauhut, D. (2011). Den besvärliga fattigdomen [The Troublesome Poverty]. 2nd edition. Lund: Studentlitteratur.

Rauhut, D. (2013). Barnfattigdomens orsaker [The Causes of Child Poverty]. In: Rauhut, D. (Ed.) Barnfattigdom [Child Poverty]. Lund: Studentlitteratur.

Rauhut, D. \& Kahila, P. (2008). The Regional Welfare Burden in the Nordic Countries. Nordregio Working Paper 2008:6.

Rauhut, D. \& Kahila, P. (2012). Youth Unemployment, Ageing and Regional Welfare: The Regional Labour Market Policy Response to Ageing in Sweden. European Spatial Research and Policy 19 (1), 111-127.

Rauhut, D., Lingärde, S. \& Alander, N. (2006). Om barnfattigdom [On Child Poverty]. Stockholm: FoU-enheten Stadsledningskontoret.

Rautio, K. (2002). Att vara fattig i storstaden eller att "ha sitt Amerika strax bortom grantopparna": Fattigvårdsutgifter $i$ ett regionalt perspektiv 1920-1955 [Being Poor in the Big City or "Having One's America Just Behind the Firs": Poor Relief Expenses in Regional Perspective 1920-1955]. Licentiatuppsats, Ekonomiskhistoriska institutionen, Umeå Universitet.

Ringen, S. (1987). The Possibility of Politics. A Study in the Political Economy of the Welfare State. Oxford: Clarendon Press.

Salonen, T. (1994). Välfärdens marginaler [The Margins of Welfare]. Stockholm: Publica.

Salonen, T. (2002). Barns ekonomiska utsatthet under 1990-talet. Bidrag till ett kommunalt barnindex [Children's Economic Vulnerability during the 1990s. Contribution to a Municipal Child Index]. Stockholm: Rädda Barnen.

Salonen, T. (2012). Barns ekonomiska utsatthet i Sverige. Arsrapport 2012 [Children's Economic Vulnerability in Sweden. Annual Report 2012]. Stockholm: Rädda Barnen. 
SCB (2012). Inkomstfördelningsundersökningen 2007 [The Investigation on Income Distribution 2007]. HE 21 SM 0901, corrected version 25 January, 2012.

Socialdepartementet (2001). Urfattigdomsfällan. Slutbetänkande från Familjeutredningen SOU 2001:24 [Out of the Poverty Trap. Swedish Government Official Report 2001:24]. Stockholm: Fritzes.

Socialdepartementet (2004). Ekonomiskt utsatta barn -En delrapport om kommunernas arbete med barnperspektivet $i$ handläggningen av ekonomiskt bistånd, Ds 2004:41 [Economically Vulnerable Children - On Municipalities' Work with Child Perspective in Administration of Social Assistance, Ministry Publications Series 2004:41]. Stockholm: Fritzes.

Socialstyrelsen (1997). Social rapport 1997 [Social Report 1997]. SoS-rapport 1997:14. Stockholm: Socialstyrelsen.

Socialstyrelsen (2007). Översyn av riksnormen. Uppföljning och utvärdering [The National Norm for Social Assistance. Follow-up and Evaluation]. Stockholm: Socialstyrelsen.

Socialstyrelsen (2010). Social rapport 2010 [Social Report 2010]. Stockholm: Socialstyrelsen. 